\title{
The Reinforcement of History Material with Multicultural Base on Social Studies Lessons
}

\author{
Murdiyah Winarti \\ Universitas Pendidikan Indonesia \\ Bandung, Indonesia
}

\author{
Yani Kusmarni \\ Universitas Pendidikan Indonesia \\ Bandung, Indonesia
}

\begin{abstract}
In social studies education, history is included as one of social sciences responsible in making good citizens. The role of history as one of the foundation for social science education especially for the growing values is to grow the sense of belonging and sense of solidarity, which are required to establish a national identity. The role can be seen in the effort to make the process of self-identification as part of members of a nation (Indonesia), the pluralistic one. One of the characteristics of Indonesian people is pluralism, in terms of various ethnic groups, religions, and languages. To establish and maintain the pluralism, effort is neededto build the attitudes of mutual respect, acknowledging the existence and the cooperation among people. Regarding this matter, socialization and wide and depth understanding of multiculturalism will enable people to grow the attitude of mutual respect for ethnic and cultural diversity. Inter-ethnic relations could not be just simply a motto (Bhinneka Tunggal $I k a$ ), or just a symbolic recognition. There must be a real effort to realize the expected life. Social studies learning and especially the reinforcement on the national history material that shows togetherness, tolerance and respect for ethnic/culture diversity (multiculturalism) are expected to increase students' empathy (sympathy and tolerance) toward others.
\end{abstract} history

Keywords-multicultural, Social Studies Education, national

\section{INTRODUCTION}

Towards the XX century, Indonesia is facing hard situation for the continuation of national integration. The dispute between ethnics, groups, or religion has colored the life in the nationhood and statehood. The examples of the dispute are the conflict between Dayak and Maduranese in Sambas Kalimantan, the conflict in Poso-Sulawesi between Moslems and non-Moslems, in Lampung between local citizens with plantation owners, the fights between the villages and between the students and so on. The national motto of Bhinneka Tunggal Ika which has the meaning 'unity in diversity' shows that the different condition of Indonesian people seen from ethnic, culture, languages and religions should not cause the disunity, but rather to strengthen the sense of unity. Thus, the commitment leads to a sense of responsibility which later createsa sense of belonging and a sense of ties among Indonesian people. In the life of diverse community, a recognition of difference must be accompanied with the awareness to respect others as a foundation toward the ideals to reach the goals together.

When threat of disintegration appears to destabilize the bonds of the Unitary State of Republic of Indonesia (NKRI), it must be confronted by all components of the nation. One of the ways to recognize the importance of struggle of this nation toward the integration process is through the history material. Through history material, the national consciousness can be embedded in teaching and learning processand the development of national identity to students can be also strengthened. The selection of learning materials, the examples used as the illustration in learning process, and the books recommended for general reading, can be used as sources that can influence the development of the unity spirit. The material in learning history that explains the struggle of mankind in the past must have the potential to be learned and applied in present life to make it more meaningful. National history material with the good package, adjusted with levels of education, is expected to directly contribute to achievement of the big goal towards the civic education.

The story of history to the education interest must be able to build and develop the collective memory of the nation. On the other hand, the collective memory might not be in the form of knowledge when they never learn history. Regarding the background stated, this article offers one alternative related to strengthening of the history learning materials that show togetherness, and invite the life of full of respect for ethnic and cultural diversity (multiculturalism). Inter-ethnic relations could not simply a motto (Bhinneka Tunggal Ika), or only symbolic recognition, there must be a real effort to realize the expected life. This article presents how the spirit of multiculturalism in history text books at High School grade XI was delivered, and how the material that already exists was developed as a form of reinforcement or enrichment.

\section{LITERATURE REVIEW}

\section{A. The Relevance of History in Social Studies Lessons}

The term social studies (IPS, its acronym in Bahasa Indonesia) appears as a concept for education in social sciences in every schools' environment, that is an education 
program in the school level and LPTK, not a sub-discipline of its own. Social Studies education to the primary and secondary education level is the simplification, adaptation, natural selection and modification of academic discipline and social sciences that are organized scientifically and pedagogical-psychologically for educational purposes [1]. Simplification means lowering the difficulty level of social sciences that are usually studied in universities to become lessons in accordance with theway of thinking of primary and advanced students. Simplification also involves channeling and integrating the material from the various branches of social sciences and the community life, so the material becomes the easily understood lessons.

Historically, the inclusion of Social Studies as a subject in the primary education (elementary school), the middle and secondary level (Middle and High School) appears simultaneously with the imposition of the 1975 curriculum. For Elementary and Middle School, the substance of subjects is integrated, but now in the 2013 curriculum social studies subjects are presented thematically (Elementary School), Middle School remain integrated, while in High School served separately. As part of the Social Studies, the matter in learning history that explains the struggle of mankind in the past must have the potential to be learned and applied in present life to make it more meaningful. Therefore, there should be connection the experience in the past with contemporary and complex life problems so that the students will understand history more easily, and Social Studies that contains the history material will be more meaningful. This contextual approach can be developed because it will help teachers to connect the material that is taught to students' real situation (the daily lives in their surroundings), so the local history learning will be more productive and meaningful [2]. Meanwhile, it is also said that developing local history learning can be done with associates on contemporary social issues in students' environment [3]. Learning history means guiding someone to learn something, and teachers must be able to catch the various dimensions and the very wide concept in the past [4].

According tothe 2013 curriculum in the school program, especially in High School level, the history subject is part of the social science interest group, including social sciences (IPS), which is taught separately as other social sciences. As we discussed previously, the role of history as one of the foundation for Social Studies education especially for growing values is expected to grow the sense of belonging and sense of solidarity, as well as the efforts to make the process of self-identification as part of members of a nation (Indonesia) [5]. It is in line with Kartodirdjo who states that it does not need to be beyond doubt that the teaching history has the purpose of inculcating national consciousness, as well as has an important function to strengthen the development of national identity [6]. In this case, the story of history can be offered to students as a means of providing the opportunity. Meanwhile the purpose of Social Studies education is to train students to have the ability to recognize and analyze something that occurs in their surroundings from different angles comprehensively. The same information is also conveyed that Social Studies education aims to develop the skills to think, attitudes and students' values as individuals as well as social and cultural beings.

The material in learning history that explains the struggle of mankind in the past must have the potential to be learned and applied in present life to make it more meaningful. National history material that is packed well and adjusted with education levels, can assist to achieve the big goal in civic education (citizenship education), so it should be taught [7]. More detail, Brian Garvey and Mary Krug [8] identify that learning history has some meanings:

1. to acquire knowledge of the historical facts,

2. to gain an understanding or appreciation of good past events or periods or people,

3. to acquire the ability to evaluate and criticize the historical writing,

4. to learn the techniques of historical research,

5. to learn how to write history.

Generally, history education at the elementary and middle schools still refers to the first and second purposes, while at high school history education has touched some of third and fourth purposes. The reinforcement of history material in high school should also consider about it, not only learning about historical facts, but also improving the ability to assess and criticize the history paper.

\section{DISCUSSION}

The history of multiculturalism is the history of pluralist society, where the United States, Canada, and Australia are known as the countries that succeeded in developing the multicultural community. The three countries can build the identity of nationhood, without removing the identity of their previous culture. For Indonesia itself the fact shows that this country has all the terms and conditions to disunite. Even though the differences and diversity still exist, Indonesia can unite. Unfortunately, at the end of XX century, there had some upheavals in some places in Indonesia related to problems of ethnic, religion, race, and groups, usually called as SARA in Bahasa Indonesia. Therefore, the attempt to identify, respect, and invest the sensitivity of socio-culture is very important.

According to Supardan, the principle in the study of ethnic relations is needed to understand the different cultures, so the desire to learn a different ethnic cultureswould appear; furthermore, principle in multiculturalism invites people to living life full of respect to other ethnics and respect the cultural diversity [9]. If those two principles are implemented consistently, it will be able to reduce conflicts that occur.

The reality on the field (schools) indicates that the history materials selected as source of Social Science lessons for students in High School do not change, or can be said to remain the same from time to time. The fact is that there are plenty of interpretations and not many follow the 
development of the various results of the latest and newest historical research. In addition, the understanding is still textual rather than contextual learning. This is possible because the history material as learning resources developed from school curriculum is the representative of the struggle of political, cultural, economic and compromise [10]. This seems fair, even though the historical writing is keep growing, especially with the existence of new information and also the existence of new descriptions.

Related to this paper, we see that spirit of multiculturalism in history text books in High School grade XI semester 2 copyrighted by the Ministry of Education and Culture RI [11], has not yet been delivered explicitly. In chapter 5 entitled 'Indonesia Merdeka', there are 3 topics of Rengasdengklok until Jalan Pegangsaan Timur; analyzing the formation of the Unitary State of Republic of Indonesia (NKRI); imitating the struggle of Proclamation figures, anddescribing the Indonesia's preparation to establish the independent state of Indonesia. Not many lifes related to multiculturalism are described in this chapter although there were opportunities, especially the imitation of the struggle of proclamation figures, the formation of state agencies, the formation of cabinet and the formation of various political parties. Meanwhile, in chapter 6 entitled 'The Revolution to Established the Greatness of NKRI' there are 3 discussions. They are "Analyzing the Development and Challenges of the Early Independence; Evaluating the Nation Struggle between War and Peace; and Practicing the Values of Revolution Struggles, which have more opportunities to insert the elements of multiculturalism. It is clear that in the previous chapter, multicultural life has not been touched intensively. This situation can be understood since the pages of textbooks are limited and there are the election of certain topics, so there are (many) things which are not revealed/ outlined.

There are still many topics that have not been explored yet that are filled with multiculturalism elements and it can be developed by history/social studies teachers to strengthen the material in text books. The selection of learning materials, the examples used as the illustration in learning, the books that are recommended for general reading can all be used as a source to develop the spirit of unity/ integration of nations [12]. Furthermore, in the process of how the material was developed as a form of reinforcement or enrichment, we take one example of physical revolution which almost all areas/ places in Indonesia have experienced. This event is one of topics that are carried on history textbooks in High School grade XI semester 2. Therefore, as the reinforcement of materials, teachers should add/provide information about revolution events that happened in their surroundings (the city where the schools are located), which show that the attitudes of respect for differences, tolerance, and mutual respect to others (multiculturalism) in local community. As revealed by the Sparring, multiculturalism is the belief, where ethnic groups/ culture can live peacefully in the principle of co- existence which is marked by their willingness to respect other cultures [13].

Reinforcing the multicultural-based national history materials can be done by transferring the examples from the local history as the material attachment from the material that has been there or available. In this case a teacher must seek and develop history material (social studies) close to the environment around students' life (local), while the textbook provides information about national events. The events that occurred at the local level can be a binding node nation, so local history can enrich the national history, even local history can be used to strengthen or to check the generalizations about the events on the national level [14]. The most important thing is that local history usually helps communities to overcome barriers between schools and the real world. This can be reached only when they understand about the importance of the right use of local material [14]. From this point, the contextual approach can be developed because it will help teachers to connect between the material that is taught with the real students' situation (the daily lives in their surroundings), so that local history learning could be more productive and meaningful. For example, it is reflectedin multicultural attitudes in Yogyakarta during the revolution of independence that can be used to explain the chapter 6 of text books, such as the existence of the Kelaskaran Council Center and Seberang; the continuation of the first Youth Congress; the return of Siliwangi army (The migrate of Siliwangi), and so on.

First, the youth soldiers from various regions joined TRI to form the Kelaskaran Council Center and Seberang on November 12, 1946 in Yogyakarta. Those laskar soldiers in Yogyakarta become more various, and the representatives of each province in Indonesia were almost here. This shows that Yogyakarta as the capital city and it positions itself as a center in unifying the whole powers of RI. Although the most members who joined the camp soldiers were the youth with their different backgrounds (ethnic, religion, culture), they showed the attitude of tolerance, togetherness and mutual respect between them. The reflection of community lives that honors the multiculturalism, duty and responsibility toward the nation and country has been uniting themselves.

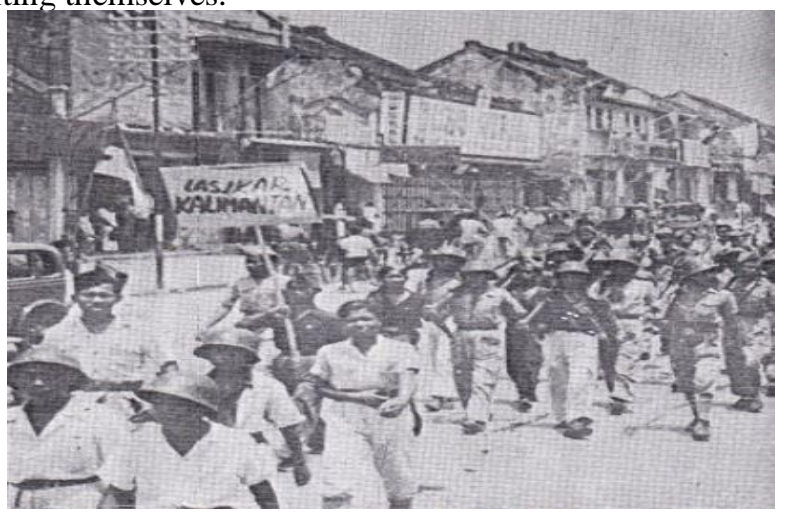

Fig 1. Kelaskaran Council Center and Seberang in Yogyakarta (Source: Sekretariat Negara RI. (1981). 30 Tahun Indonesia merdeka. Jakarta: Sekretariat Negara, 121). 
Second, the Youth Congress I of the Republic of Indonesia held on 10-11 November 1945 was attended by representatives as follows: 400 of Javanese, 11 of Kalimantanese, 9 of Sulawesinese, 25 of Malukunese, 18 of Sundanese, and 166 of Sumateranese [15]. This also shows that the youth from various regions who have different characters, culture, language, and faiths can work with one another, to realize the common interests for Indonesia. The life of multiculturalism can be taken as an example for students in their daily lives, so brawls between students, inter-villages, inter-ethnic and others can be avoided.

Third, there are emigration events involving the Siliwangi Army from bags of guerillas who had to go into the territory of Republic (Central Java and Yogyakarta) in February 1948 [16]. An estimated of 35,000 TNI members migrate to the Republic and first divisions of the Siliwangi Army has arrived in Yogyakarta on 11 February 1948. They were welcomed by local citizen, including General Soedirman, other military officials and other civilians. Their arrival to the Republic territory took some progress gradually because the transportation that used was limited, while the number of people who would migrate was quite a lot. With the little supplies, such as clothes and a small preparation, it was indeed a sacrifice that was not easy to describe. In addition to having a very long traverse, most of them were forced to leave their family for a time that cannot be ascertained. The local leader and half of citizen in Yogyakarta personally provide their money or dwelling place for those in need. They did not hesitate to give relief to soldiers who came to Yogyakarta, nor to the laskar fighters. It can be defined as the form of tolerance to those who need without distinguishing the status, classes, ethnic, religious and others. The life that upholds the true multicultural society has been made in the time of revolution, but real examples are not much used as material in learning at school.

Those examples are definitely very simple and limited, but at least they give a description to teachers, especially teachers who will reinforce in the matter of national history multicultural based material through local history. Not just appears knowledge recitation, but there are many things that can be revealed. Sympathy, empathy, also other values such as multiculturalism, nationalism, patriotism and tolerance can be developed on students. This will need to be done, so that students can use the imagination to solve the historical problems, and grow empathy among them toward things that have been done by fighters in the past [17]. At the end, this is expected to help students to understand the material learned as better and meaningful knowledge.

\section{CONCLUSION}

Not all of history materials are appropriate to be developed as the reinforcement in describing multiculturalism. In this case, a teacher must seek and develop history material (Social Studies) close to the environment around students' life (local), while the textbook provides the national information. Related to this, teachers must be skillful to choose and have an extensive reference if they want to develop history materials as the reinforcement in Social Studies lessons. If the focus is only on the existing textbooks, it can ascertain that students will not get the material that will improve their understanding about multiculturalism.

Local history can provide a wider space, so that learning history/Social Studies become more interesting because they are always associated with the phenomenon that occurs around students' life. Local history not only enriches the national history, but more importantly deepens the knowledge about the dynamics of socio-cultural from Indonesian society. Local history also attaches the 'autonomous' socio-cultural aspects. It has a strategic role and provides a possibility in developing national history learning materials. As said by Sartono "Often, things in the national level can be understood by looking at what happens at the local level, because things that are present in a larger area usually provide an overview of patterns and the problems generally, while the more detailed and concrete situation can be known through the description of local history".

\section{REFERENCES}

[1] N. Soemantri, Menggagas pembaharuan pendidikan IPS, Bandung: Remaja Rosda karya, 2001, pp 103

[2] M. Winarti, "What is and how to improve the local history material in history learning", Historia: Jurnal Pendidikan Sejarah, No. 2, Vol . XIII, hlm. 201-206, Bandung: Jurusan Pendidikan Sejarah FPIPS UPI dan Association of History Educators and Researchers, pp 214, 2012, pp 214.

[3] N. Supriyatna, "Konstruksi pembelajaran sejarah local untuk memahami isu-isu sosial", Historia: Jurnal Pendidikan Sejarah. No.11, Vol.V1, Bandung: Jurusan Pendidikan Sejarah UPI, 2005, pp 113-133,

[4] E. Wiyanarti, "Mengemas masa lampau kedalam kelas: sebuah model garis waktu dalam pelajaran sejarah", Historia: Jurnal Pendidikan Sejarah, No.2, Vol.1, hlm. 68-76, Bandung: JurusanPendidikanSejarah UPI, 2000, pp 69

[5] R. Wiriaatmadja, Peranan pengajaran sejarah nasional Indonesia dalam pembentukan identitas nasional (upaya peraihan nilai-nilai integralistik dalam proses sosialisasi dan enkluturasi berbangsa di kalangan siswa SMAK I BPK Penabur di Bandung, Bandung: Disertasi, SekolahPascaSarjana PIPS IKIP, 1992, pp 12

[6] S. Kartodirdjo, Pemikiran dan perkembangan historiografi Indonesia suatu alternatif, Jakarta: Gramedia, 1982, pp 248.

[7] J. Jarolimek, Social studies in elementary education, New York: Macmillan Publishing Company, 1986, pp 146

[8] B. Garvey \& K. Mary, Model of history teaching in the secondary school, Kidlington, Oxford: Oxford University Press, 1977, pp 2 - 5

[9] D. Supardan, "Peluang Pendidikan dan Hubungan Antaretnik: Perspektif Pendidikan Kritis,, dalam Jurnal Kajian Ilmu Sosial, Jakarta : UIN Syarif Hidayatullah, 2008, pp 37

[10] Crawford, Keith, www.centres.exeter.ac.uk

[11] Kementrian Pendidikan dan Kebudayaan RI, Pelajaran Sejarah di Sekolah Menengah Atas Kelas XI semester 2, Jakarta: Kementrian P dan K RI, 2014. 
[12] S. K. Kochhar, Pembelajaran sejarah, teaching of history, Jakarta: Gramedia, 2008, pp 475

[13] D.T. Sparringa, Multikulturalis medalam Multiperspektif di Indonesia, Surabaya: Forum RektorSimpulJawaTimurUniversitas Surabaya, 2003, pp 17

[14] R. Douch, Local history and the teacher, London: Routledge\& Kegan Paul, 1967, pp 3 - 7.

[15] H. Basskoro, and S. Sunaryo, Catatan perjalanan keistimewaan Yogya, Yogyakarta : Pustaka Belajar, 2010, pp 159

[16] H. Soetanto, Yogyakarta, Jenderal Spoor (OperatieKraai) versus Jenderal Sudirman (Perintah Siasat No. 1), Jakarta: Gramedia, 2006, pp 115

[17] A. Suwirta \& D. Saripudin (ed.), "Sejarah dalam perubahan, penghormatan 70 tahun Prof. Dr. H. Ismaun, M.Pd.”, (hlm. 175194), Bandung: Historia Utama Press, 2005, pp 180-181 